\title{
THE NEW REGIME IN NATURAL GAS PRICING IN ALBERTA
}

\author{
FRANCIS M. SAVILLE*
}

\begin{abstract}
Traditionally, the price of petroleum and natural gas in Canada has been relatively low. However, recent changes in the international market have placed pressures upon the federal and provincial governments to reassess the pricing of these commodities. As a consequence, Alberta has, in an effort to raise natural gas prices, passed the Arbitration Amendment Act, which forces the field price of gas towards the commodity value and the Natural Gas Pricing Agreement Act, which acts as an agreement with the federal government regarding natural gas prices. At the same time, the federal government has enacted the Petroleum Administration Act to regulate the price of crude oil and natural gas. This article discusses the various acts, in particular the Natural Gas Pricing Agreement Act, as well as the constitutionality of such legislation and the future pricing of natural gas in Canada.
\end{abstract}

\section{INTRODUCTION}

In the past two years Canada has been exposed to dramatic changes in the oil and gas industry. Almost limitless quantities of natural gas at a relatively low price were a part of the Canadian way of life that were taken for granted in many parts of our country. As is pointed out in the historical review in the succeeding paragraphs, the culminating effect of these changes appears in the form of new statutory rules over the pricing of natural gas across Canada.

It is the purpose of this paper to examine the Petroleum Administration Act $^{1}$ as enacted by the Parliament of Canada, the Natural Gas Pricing Agreement Act, ${ }^{2}$ as well as the Natural Gas Price Administration Act, ${ }^{3}$ the latter two being enacted by the legislative Assembly of the Province of Alberta and finally, the Dominion-Provincial agreement on the subject of natural gas pricing as reflected in letters exchanged between the Ministers dated October 17, 1975.

\section{HISTORY}

A quadrupling of oil prices on the international scene from 1973 to 1975 severely affected the stable pricing, taxation and political environment surrounding the exploration, development, processing and sale of crude oil and natural gas in Canada. These disruptions manifested themselves in uncertainty for the petroleum and natural gas industry both economically and philosophically. Specifically, the pricing problems which arose out of jurisdictional, constitutional and political squabbles have been one of the major areas of concern to the industry and to the country as a whole.

As a result of the difficulties encountered by the federal and provincial governments in their attempts to arrive at a national price for petroleum and natural gas in 1974 and 1975, First Ministers' Conferences were held. The result was to raise the average wellhead price of

\footnotetext{
- Barrister and Solicitor, Fenerty, Robertson, Prowse, Fraser, Bell and Hatch, Calgary, Alberta.

1. S.C. 1974.75 , c. 47.

2. S.A. 1975 , c. 38 as amended.

3. S.A. 1975 , c. 70.
} 
crude oil from $\$ 3.80$ per barrel to $\$ 6.50$ (April 1, 1974). The corresponding wellhead price for gas (1973) had been about 224 per mcf which price was soon to change largely by reason of the introduction in the Alberta Legislature of The Arbitration Amendment Act. ${ }^{4}$ The intent of this Act was to, in effect, amend gas purchase contracts that contained arbitration clauses for redetermination of the price of gas. This Act sets out a series of rules that the parties must abide by in redetermining the field value, the result of which was to direct that the field price of gas climb toward commodity value. Commodity value was defined as being the aggregate of sale value of gas in reference to volume-weighted average prices of substitutible energy sources competing on the consuming markets minus the necessary transportation and distribution costs from the point of sale of the gas to the burner tip.

Pursuant to the Arbitration Amendment Act, ${ }^{5}$ Gulf Canada initiated arbitration proceedings with TransCanada PipeLines and following a lengthy hearing under the rules of the new statute, the three man arbitration panel set a field price of 604 per mcf for the first year (effective November 1,1974 ) and a second field price of 734 per mcf for the second year of the price redetermination (effective November 1 , 1975). TransCanada PipeLines launched an appeal to the Supreme Court of Alberta alleging, among other grounds, that the Arbitration Board had no jurisdiction under the Act to set two different prices. The appeal was subsequently settled on the basis that the 604 price for the first year would remain but that the 734 figure would be discarded in favour of an agreement wherein the producer was entitled to redetermine the price under the gas purchase contracts on an annual basis.

The first arbitration was followed by a second which again was initiated by Gulf Canada for the contract period starting November 1, 1975. After a second lengthy hearing in the spring of 1975, the second arbitration panel set the new field value at $\$ 1.15$ per mcf. The second Gulf arbitration award was to some degree even more significant than the first to the extent that larger volumes of gas were being affected by the second decision as many other producers had agreed with TransCanada to be bound by the Gulf arbitration award.

The federal government's reaction to the $\$ 1.15$ award, as expressed by the then Minister of Energy, Mines and Resources, Donald Macdonald, was that he felt an increase of those proportions was dramatic and that while he did not quarrel with the commodity value concept, he felt that the phasing of the price of natural gas to commodity value should occur over a period of years.

The Petroleum Administration Act ${ }^{6}$ was then passed by the Parliament of Canada and served as a basis for continued negotiation between the Government of Canada and the Province of Alberta over what the price of natural gas effective November 1, 1975, was to be. These negotiations culminated in the agreement reached between Ottawa and Edmonton as reflected in the letters dated October 17, 1975, and which agreement served as the basis for passage of the Natural Gas Pricing Agreement Act ${ }^{7}$ in the Alberta Legislature in late 1975 but effective November 1,1975 . The result was that the price of natural gas

4. S.A. 1973 , c. 88.

5. Id.

6. Supra, n. 1 .

7. Supra, n. 2. 
was agreed to based on a Toronto City gate price of $\$ 1.25$ which, when backed-off to the Alberta border, totals 834 and which, with the deduction of the cost of service within Alberta, becomes 724 in the field.

One further comment should be made about the Arbitration Amendment Act. ${ }^{8}$ The Natural Gas Pricing Act, ${ }^{9}$ as well as the Natural Gas Price Administration Act ${ }^{10}$ (which is an Act similar to the Natural Gas Pricing Agreement Act but is contemplated for use in the absence of an Ottawa-Alberta agreement on the pricing of natural gas), supersede the Arbitration Amendment Act to the extent that no arbitration is effective if its award exceeds the field value set by the new legislation. In other words, notwithstanding section 11 of the Natural Gas Pricing Agreement Act, the right to redetermine the price under the Arbitration Amendment Act still exists but in terms of result, it is now illegal by virtue of the Natural Gas Pricing Agreement Act, to sell the gas at a price higher than the regulated field price.

One should also make reference to the history of the pricing of natural gas that is exported to the United States. As of November 1, 1974 the export price had been decreed by the National Energy Board to be not less than $105 \%$ of the price paid by TransCanada consumers in the western zone $(64 \uparrow)$.

On January 1, 1975 the border price was increased to $105 \%$ of $\$ 1.00$ for a price of $\$ 1.05$ per mcf.

On July 1,1975 the price was further increased to $\$ 1.40$ for a border price. The last increase took place in November, 1975 when the price was raised to $\$ 1.60$ per mcf.

\section{FEDERAL LEGISLATION}

The Petroleum Administration Act ${ }^{11}$ establishes a scheme to regulate the price of Canadian crude oil as well as natural gas and the interprovincial export trade of both. In particular, Division III of the said Act provides for the controlling of natural gas prices. Section 49 sets out the purpose of Division III of the Act, namely:12

49. (a) to achieve a uniform price, exclusive of transportation and service costs, for gas used in Canada outside its province of production;

(b) to achieve a balance in Canada between the interests of consumers and producers in Canada;

(c) to protect consumers in Canada from instability of prices for gas and to preserve a reasonable balance between the prices of alternative fuels in Canada; and

(d) to encourage the discovery, development and production of a supply of gas adequate to the self-sufficiency of Canada.

The purposes, as set out in section 49 , can be achieved under this statute in two ways:

(a) Under section 50 by way of an agreement between the Governor in Council and the government of a producer-province (which is the way the present price has been arrived at); or

(b) Where there is no pricing agreement between the federal
8. Supra, n. 4.
9. Supra, n. 2 .
10. Supra, n. 3.
11. Supra, n. 1.
12. Supra, n. 1. 
government and a producer-province for whatever reason, the Governor in Council may "prescribe prices at which the various kinds of gas to which this part applies that are produced, extracted, recovered or manufactured in that province are to be sold on or for delivery in any areas or zones in Canada and outside that province or at any points on the international boundary of Canada".13 (emphasis supplied)

It is rather interesting to observe that under section 52 , the Government of Canada only assumes jurisdiction over the pricing of natural gas upon the gas entering into interprovincial or international trade.

Section 51(2) contains the criteria to be used by the Governor-inCouncil for establishing prices of natural gas in the case of an agreement with a producer-province and it is of significance to note that the concept of commodity value in interprovincial markets is recognized by virtue of (c) of this section although this statutory statement is not nearly as strong as the language of the Alberta Arbitration Amendment Act.

A second major function of the Petroleum Administration Act in relation to natural gas pricing, is contained in section 64 which decrees that any additional revenues received by gas purchasers for gas sold for export at any point on the Canadian boundary is to be returned to the producers minus any cost of service incurred by the purchaser including the cost of purchasing the gas.

\section{PROVINCIAL LEGISLATION}

As has already been mentioned, the Province of Alberta passed two statutes, the first (the Natural Gas Pricing Agreement Act) being designed to operate in the context of an agreement with the federal government regarding natural gas price and which is the statute that the industry is operating under at the moment. The second statute (the Natural Gas Price Administration Act) is analogous to section 52 of the Petroleum Administration Act in that it contemplates the setting of natural gas prices by the province in the absence of an agreement between the Alberta Government and the government of Canada.

With minor exceptions, the two statutes are similarly worded and the ensuing discussion will therefore only revolve around the Natural Gas Pricing Agreement Act.

An analysis of the Natural Gas Pricing Agreement Act indicates that it is designed to give the Minister of Energy and Natural Resources two functions:

(a) To determine the price to the producer for gas;

(b) To distribute to all producers the excess monies flowing from gas sales to the United States.

With respect to the first function, section 10 of the Act determines prices and the price depends on the destination of the gas. If the gas is intended to be removed from Alberta, then the price is the Alberta border price plus the price adjustment less the Alberta cost of service. If the gas is to be consumed in Alberta the price is the lesser of the Alberta border price plus the price adjustment less the estimated Alberta cost of service or the contract field price plus the price adjustment. 
It is important to note that for gas sold for consumption in Alberta, there is flexibility in price. An upper limit is placed, the Alberta border price plus price adjustment less an amount estimated as the Alberta cost of service (the cost of service if that gas were to be removed from Alberta). To determine the upper limit, the buyer must obtain the estimated Alberta cost of service. To date this uniformly has been 7.64.

To the extent the contract price is less than this amount, the contract price remains in effect. The parties are also free to negotiate or by arbitration, move this price upwards. It will become ineffective only when it surpasses the upper limit imposed by the Act.

The second function of distribution of proceeds from export sales is set out in sections 14 and 16. The price adjustment functions such that the Minister purchases a majority of gas in the province and this includes all the gas which is sold to the United States. The gas which is sold into the United States is purchased by the Minister for the Alberta border price less the Alberta cost of service and is resold to the owner at the international price, less the Canadian cost of service and the Alberta cost of service. The resultant excess is retained by the Minister. All other gas is purchased and resold at the same price.

The excess is held in the National Gas Pricing Agreement Act fund. The Minister (Alberta Petroleum Marketing Commission) determines the monthly total (excess) monies divided by total gas produced which results in a price adjustment figure of approximately 234 per MMBtu. This is then distributed to all producers as it is a part of the purchase price paid for gas (price adjustment) by original buyers. Original buyers in turn are reimbursed from the fund upon application to the Alberta Petroleum Marketing Commission.

Other owners of eligible gas may apply for and obtain price adjustments.

The general scheme under which the Act works is that the Alberta government, through the Minister of Energy and Natural Resources, takes ownership of nearly all gas produced in Alberta whether or not the particular gas stream is destined for an ex-Alberta market. Pursuant to orders of the Minister the owners of the gas are instructed to deliver the gas to him at specific points, i.e. Empress and Cochrane. The gas is then sold by the Minister back to the same party from whom it was purchased.

Where an "original buyer" purchases gas under a "gas sales contract" and the gas is intended to be removed from Alberta, the purchase price of such gas in any month shall be the Alberta border price (834) plus the "price adjustment" (234) less the Alberta cost of service (94) with respect to the gas (see s. 14(3)(a)). Using the numbers bracketed above in an example a producer in Alberta selling to TransCanada under a gas sales contract where the gas is destined for Ontario would receive approximately 954 per mcf for that gas.

Where an "original buyer" purchases gas under a gas sales contract for consumption in Alberta the purchase price of such gas in any month will be the lesser of the existing contract price (as an example 504) plus the "price adjustment (234) or the Alberta border price (834) plus the "price adjustment" (234) less the "Alberta cost of service" (94) with respect to the gas. Using a similar example if a producer sells to Northwestern Utilities under a standard gas sales contract and using 
the numbers bracketed above the producer will receive 644 per mcf. Clearly the Alberta consumer pays less for his gas while at the same time the producer still benefits from the sale of the gas exported to the United States.

The "original buyer" is entitled to reimbursement for the "price adjustment" paid by him and these monies are received by applying to the Alberta Petroleum Marketing Commission who is charged with the responsibility of administering the Act. Reference should also be made to 8. 15 of the Act which gives the Minister power to control the removal of any gas constituent other than methane. It can be noted in $\mathbf{s}$. 15(2) that the Lieutenant-Governor-in-Council retains the right to have the constituents removed upon being satisfied that the constituent would not be removed elsewhere in Alberta and that it is in the public interest to remove it. In the event that constituents were being removed under this section there is to be created a "Natural Gas Constituents Proceeds Fund (Number 1)" and the Minister is directed by this section to pay those monies to the producers.

\section{Functioning of the Natural Gas Pricing Agreement Act}

As previously mentioned, s. 14(1) contemplates the Minister ordering that the original buyers and other designated owners of gas must deliver their gas to the Minister of Energy and Natural Resources (the Minister) at specified delivery points in the province. The gas when delivered is sold to the Minister and invoiced to the Alberta Petroleum Marketing Commission whether or not it is intended to be removed from Canada at prices designated pursuant to the agreement with the federal government and pursuant to the Natural Gas Pricing Agreement Act. The Minister then delivers the gas back to the company and the Alberta Petroleum Marketing Commission will invoice the company with an amount dependent upon the designation of the gas. The net of the invoices will be the differential revenue on gas exported from Canada and will be payable by the company to the Alberta Petroleum Marketing Commission who administers that fund (Natural Gas Pricing Agreement Fund).

The Alberta Petroleum Marketing Commission determines in each month a "price adjustment" based on the monies available in the fund and the total gas therein. The price adjustment only applies to gas delivered during that month.

Original buyers, by virtue of $\mathrm{s}$. 10 , are required to include the price adjustment as part of the price paid for gas delivered under a gas sales contract. They invoice the Alberta Petroleum Marketing Commission for reimbursement from the fund. Other owners of eligible gas, which is not subject to the gas sales contract, may also invoice the Alberta Petroleum Marketing Commission for the amount of the price adjustment which they are entitled to. These revenues are also paid out of the fund. In general, the owners of the natural gas and the Alberta Petroleum Marketing Commission working together flow gas between each other constantly and monies monthly. The original buyers must report their sales to the Commission on the 18th day of the month following the month of delivery. The Commission invoices sales back by the 20 th day of the month following the month of delivery. Net invoices are made to the original buyers on the 25th of the month following the month of delivery. All original buyers are reimbursed for the price adjustment 
they have paid out on the 25th day of the month following the month of delivery.

With respect to the cost of service all original buyers of gas in Alberta must have an approved Alberta Cost of Service for each month in which they purchase gas. Applications for Alberta Cost of Service are to be directed to the Commission. All original buyers of gas in Alberta who deliver and sell gas into export markets must also have a Canadian Cost of Service each month. This is determined by the National Energy Board and the buyer must inform the Commission of that cost.

\section{CONSTITUTIONAL VALIDITY OF THE PETROLEUM LEGISLATION}

The question of constitutional validity of the Petroleum Administration Act and the Alberta Natural Gas Pricing Agreement Act is not likely to be challenged in the courts on a constitutional basis when the regulation of gas prices is done by agreement as contemplated in the respective sections of both statutes.

The more interesting legal issue that arises is whether the Natural Gas Price Administration Act (for use by Alberta when there is no agreement) and the relevant sections under Division 3 of the Petroleum Administration Act are intra vires their respective legislatures.

The federal government would no doubt maintain that they are regulating trade and commerce within s. 91(2) of the British North America Act and perhaps in certain circumstances that the whole scheme of the control of petroleum pricing fits within the peace, order and good government portion of s. 91. On the other hand the Province of Alberta would seek to maintain that the provincial legislation fits within s. 92 under subsections 5,13 and 16 which deal with "the management and sale of public lands belonging to the Province and of the timber and wood thereon", "property and civil rights in the province" and "generally all matters of a merely local or private nature in the province". The leading decisions of the Supreme Court of Canada in this area of constitutional law are: Farm Products Marketing Act 14; Carnation Company Ltd. v. Quebec Agricultural Marketing Board 15; A.G. for Manitoba v. Manitoba Egg and Poultry Association ${ }^{16}$ and Caloil Inc. v. A.G. of Canada. ${ }^{17}$

In order to illustrate the attitude of the Supreme Court of Canada in this area of the law, reference is to be made to the statement of the now Chief Justice of Canada in the Manitoba Egg case: ${ }^{18}$

What emerges from the various reasons of the members of the court is that

(1) individual contracts for the sale and purchase of goods in a province do not engage federal power under s. $91(2)$ where any applicable provincial legislation relates merely to the terms of the contract;

(2) regulation of the marketing, or the processing and marketing, of products in a province for consumption therein is within provincial competence;

(3) regulation of the marketing of provincial produce intended for export or sought to be purchased for export is beyond that competence;

(4) regulation of production or manufacture must be distinguished from regulation of 
transactions in the product and it cannot be said that the former is so wholly within provincial regulatory competence as in all cases to cover production or manufacture for export; and

(5) even in respect of the latter, it cannot be categorically stated that ultimate extraprovincial designation will foreclose provincial regulation of intermediate steps in the marketing process. (emphasis supplied)

For a recent discussion of the pros and cons of the constitutional validity of these statutes there is an article in the University of British Columbia Law Review entitled Jurisdiction Over On-Shore Oil and Gas in Canada. ${ }^{19}$

\section{FUTURE PRICING OF NATURAL GAS}

At the present time the agreement between the federal government and the Alberta government is in operation. It would appear that it would be modified to the extent that the price of natural gas will be increased July 1, 1976 by 154 per mcf followed by a further increase effective January 1, 1977 of an additional 10.54 per mcf. It also may come to pass that the U.S. export price of $\$ 1.60$ will be increased to $\$ 2.00$ at some date in the near future and which would serve to increase the "price adjustment" paid to producers.

While it is always dangerous to speculate one can make reference to the federal goal with respect to self-sufficiency in energy as recited in $\mathbf{s}$. 49(d) of the Petroleum Administration Act. The most recent development at the time of preparation of this docurient is the statement of the Honourable Minister of Energy Alastair Gillespie in his paper entitled "An Energy Strategy for Canada" wherein the change in goals from one of self-sufficiency to self-reliance is enunciated. Or as the Minister stated: 20

Self-reliance in energy means reducing our vulnerability. It means supplying Canadian energy requirements as much as possible from domestic resources. It involves a twopronged approach: first, to reduce our oil imports to the greatest extent practicable; second, to provide an adequate degree of emergency preparedness to deal with supply interruptions if they should in fact occur.

The Minister then went on to outline the five targets for the National Energy Strategy: ${ }^{21}$

1. Moving domestic oil prices towards international levels and moving domestic prices for natural gas to an appropriate competitive relationship with oil during the next two to four years;

2. Reducing the average rate of growth of energy use in Canada during the next ten years to less than $3.5 \%$ per year. This would be a one-third reduction in the traditional growth rate of energy;

3. Reducing net dependence on imported oil in 1985 to one-third of Canada's total oil demands. Imports of oil could reach 1.2 million barrels per day by 1985 , or $47 \%$ of Canada's estimated needs. The Energy Strategy report suggests cutting that to 33\% or less-'through competitive pricing, increased exploration and development, interfuel substitution, and strong energy conservation programs.';

4. Maintaining self-reliance in natural gas until such time as northern resources can be brought to market under acceptable conditions;

5. Doubling exploration and development activity in the frontier regions of Canada during the next three years, under acceptable social and environmental conditions.

Comparing the above to the pricing of natural gas suggests that the

19. 10 U.B.C. L. Rev. 86.

20. Canada Dept. of Energy, Mines \& Resources, "An Energy Strategy for Canada: Policies for Self-Reliance," 1976 at 5-6.

21. Id. 
price of natural gas will be increased to where it is comparable to the price of oil on a heating value basis over the next two to four years. There will undoubtedly be disputes between the Alberta and federal governments over the timing of these increases. The important point being, however, that there seems to be an agreement that the price of domestic oil should continue to increase on a gradual basis tracked closely by the price of gas. 